\title{
SHORT-TERM HYDROTHERMAL COORDINATION BASED ON PRIMAL-DUAL INTERIOR POINT METHOD
}

\author{
Borče Postolov, Sofija Nikolova Poceva \\ Faculty of Electrical Engineering and Information Technologies, \\ "Ss. Cyril and Methodius" University in Skopje, \\ Rugjer Bošković bb, P.O. box 574, 1001 Skopje, North Macedonia \\ borce.postolov@hotmail.com
}

\begin{abstract}
A b s t r a c t: This paper proposes a Primal-Dual Interior Point (PDIP) algorithm for solving short-term hydrothermal power system (STHTS) scheduling problem considering power losses in transmission system, forecasted wind power and transmission line constraint. A mathematical model for solving the problem of STHTS has been developed and implemented in the MATLAB software package. The PDIP forms Lagrange function by adding an internal (barrier) penalty function, and converting all inequality constraints to equality constraints, and then Newton's iterative method is used to solve the system equations. The main advantages of the PDIP method are the large scale type and the ability to solve optimization problems with sparse matrices. The effectiveness of the proposed PDIP has been previously tested on different hydrothermal power systems and the obtained test results have been compared to those from other methods in the literature. The main purpose of this paper is to highlight the impact of transmission line constraint on the operating costs of the thermal power plants, i.e. that it should be included in the mathematical model of STHTS.
\end{abstract}

Key words: primal-dual interior point algorithm; short-term; hydrothermal coordination

\section{КРАТКОРОЧНО ХИДРОТЕРМАЛНО СОДЕЈСТВО ЗАСНОВАНО НА МЕТОДОТ НА ПРИМАРНО ДВОЈНА ВНАТРЕШНА ТОЧКА}

\begin{abstract}
А п с т р а к т: Во овој труд е презентиран и предложен алгоритам на примарно двојна внатрешна точка (PDIP) за решавање на оптимизациониот проблем на краткоротчно хидротермално содејство (STHTS), уважувајќи ги загубите во преносниот систем, предвиденото производство од ветерните електрани и ограничувањето за преносната мрежа. Формиран е математички модел за решавање на проблемот STHTS и е имплементиран во програмскиот пакет MATLAB. Со алгоритамот PDIP се формира Лагранжова функција преку додавање внатрешна (бариерна) пенализациона функција, како и претворање на сите ограничувања од типот неравенство во ограничувања од типот равенство, а потоа е користен итеративниот метод на Newton за решавање на системот равенки. Главната предност на алгоритамот PDIP е фактот што претставува метод за решавање на оптимизациони проблеми со голема димензионалност (large scale), како и способноста за решавање слабо пополнети матрици. Ефикасноста на предложениот алгоритам PDIP е претходно тестирана на различни хидротермални системи, а добиените резултати се споредени со оние од други методи во литературата. Главната цел на овој труд е да се истакне влијанието на ограничувањата на преносните водови врз трошоците за работа на термоелектраните, т.е. дека е неопходно тоа да биде вклучено во математичкиот модел на STHTS.
\end{abstract}

Клучни зборови: алгоритам на внатрешна точка; краткорочно; хидротермално содејство

\section{INTRODUCTION}

Power systems in which electricity production is from hydropower plants and thermal power plants, require special energy - economic analysis which determines how much of the available capacity of hydropower plants can be used, and how much is the power requirements of thermal power plants, in order to meet the system load demand. The main goal is to exploit their diversity so that the required production is technically and economically most favorable, i.e. to minimize the operating costs 
of the thermal power plants, as well as to achieve optimum water consumption in the hydropower plants, while satisfying a number of technical and system constraints $[1,2]$.

In complex hydrothermal power systems, hydrothermal coordination problem is carried out on an annual, monthly or daily basis. This paper will analyze the short-term hydrothermal scheduling (STHTS) for an optimization period of one day, with a resolution of one hour.

Short-term hydrothermal scheduling (STHTS) is the optimal load distribution between the committed hydropower plants and the thermal power plants, over a one day, in order to achieve the minimum fuel costs in the thermal power plants, and by using a predetermined amount of water in the reservoirs, but with the satisfaction of a number of technical and system constraints.

STHTS is a complicated nonlinear convex or non-convex optimization problem. In recent years several methods such as dynamic programming (DP) [3], network flow [4], decomposition technique [5], mixed integer linear programming (MILP) [6], and Lagrangian relaxation have been proposed. (LR) [7]. Since it is a large-scale optimization problem, as a universal method in the category of large scale algorithms, a Primal Dual Interior Point (PDIP) method for nonlinear programming will be proposed. The PDIP algorithm forms linearized equations in Newton's algorithm, using Taylor's second-order development and its iterative solution, and as a universal method gives a physically acceptable solution for the decision variables as well as the dual variables (Lagrange and Karush-KunnTucker multipliers), that are implemented to create an augmented Lagrange objective function. The Interior Point method is based on the Karmarkar's algorithm and comprises combinations of projection scaling method, dual method, primal method, primal-dual method, barrier function algorithm (internal penalty function), and Lagrange multipliers method $[8,9]$. The Interior Point method is based on the first order Karush-Kuhn-Tucker optimality conditions.

\section{KARUSH-KUHN-TUCKER CONDITIONS}

The most important theoretical basis for nonlinear programming is the Karush-Kuhn-Tucker optimality conditions. Karush-Kuhn-Tucker's conditions must be satisfied for any constrained optimal solution, local or global, for any nonlinear optimization problem. Let's review the next nonlinear optimization problem $[10,11]$ : $\min f(\mathbf{x})$, u.c. (under constraints):

$$
\begin{aligned}
& g_{j}(\mathbf{x}) \leq 0, \quad j=1,2, \ldots, J ; \\
& h_{k}(\mathbf{x})=0, \quad k=1,2, \ldots, K
\end{aligned}
$$

The inequality constraint $g_{j}(\boldsymbol{x}) \leq 0$ is active at the point $x_{0}$, if $g_{j}\left(\boldsymbol{x}_{0}\right)=0$, or is inactive if $g_{j}\left(\boldsymbol{x}_{0}\right)<0$. In general nonlinear optimization problem, the following Lagrange function can be formed, i.e.:

$$
\begin{aligned}
L(\boldsymbol{x}, \boldsymbol{\lambda}, \boldsymbol{\mu})= & f(\boldsymbol{x})+\sum_{k=1}^{K} \lambda_{k} h_{k}(\boldsymbol{x})+ \\
& +\sum_{j=1}^{J} \mu_{j} g_{j}(\boldsymbol{x})
\end{aligned}
$$

In expression (2), the Lagrange multipliers $\lambda_{k}$ correspond to the equality constraints, and the Lagrange multipliers $\mu_{j}$ correspond to the inequality constraints. The multipliers $\mu_{j}$ are also called Karush-Kuhn-Tucker multipliers. The vector $\mathbf{x}$ satisfies the Karush-Kuhn-Tucker (KKT) conditions for the non-linear programming (Nonlinear Programming Problem - NLPP), if there is a pair of vectors $\boldsymbol{\lambda} \in R^{K}$ and $\boldsymbol{\mu} \in R^{J}$, so that:

$$
\begin{gathered}
\nabla L=\nabla f(\mathbf{x})+\sum_{k=1}^{K} \lambda_{k} \nabla h_{k}(\mathbf{x})+ \\
+\sum_{j=1}^{J} \mu_{j} \nabla g_{j}(\mathrm{x})=0 \\
h_{k}(\mathbf{x})=0, \quad k=1,2, \ldots, K \\
g_{j}(\mathbf{x}) \leq 0, \quad j=1,2, \ldots, J \\
\mu_{j} g_{j}(\mathbf{x})=0, \quad j=1,2, \ldots, J \\
\mu_{j}>0, \quad j=1,2, \ldots, J
\end{gathered}
$$

Conditions (3) - (5) are from constrained optimization with equality constraints through the Lagrangian multipliers method. The condition (6) is called condition of complementarity, and is defined as follows. If the $j$-th constraint is inactive, i.e. $g_{j}\left(\mathbf{x}_{0}\right)<0$, then $\mu_{j}=0$, so is true that $\mu_{j} g_{j}\left(x_{0}\right)=$ 0 . Otherwise, if the $j$-th constraint is active, i.e. $g_{j}\left(\mathbf{x}_{0}\right)=0$, then it is not necessary for the multiplier $\mu_{j}$ to be equal to zero, since it is already fulfilled that $\mu_{j} g_{j}\left(\mathbf{x}_{0}\right)=0$. An additional condition is that the multiplier $\mu_{j}$ must be a greater than zero, as shown in the non-negativity condition given by the expression (7).

\section{PRIMAL-DUAL INTERIOR POINT ALGORITHM}

Primal-Dual Interior Point (PDIP) method marks a major development since 1984, when he appeared as projective Interior Point (IP) algorithm, 
which was proposed by Karmarkar [12]. The basic Interior Point algorithm dates back to earlier times, with the most significant contribution being made by scientists: Frisch [13], Dikin [14], Fiacco and McCormick [15] and Khachiyan [16]. This section will present the mathematical model of the PDIP algorithm, which is used to solve nonlinear problems. The general nonlinear optimization problem, as noted earlier, is generally formulated according to expression (1), where $\mathbf{f}(\mathbf{x}), \mathbf{x}, \mathbf{g}_{j}(\mathbf{x})$ and $\mathbf{h}_{k}(\mathbf{x})$ are objective function, decision variables vector, a inequality constraint functions vector and a equality constraint functions vector, respectively. What needs to be emphasized in this method, is that before proceeding to solve the above nonlinear problem, the PDIP transforms the inequality constraints into equality constraints by adding additional positive variables, i.e: $\min \mathbf{f}(\mathbf{x})$, u.c.:

$$
\begin{array}{ll}
\mathbf{g}_{j}(\mathbf{x})+\mathbf{s}=0, & j=1,2, \ldots, J \\
(\mathbf{x})=0, & k=1,2, \ldots, K \\
\mathbf{s} \geq 0 &
\end{array}
$$

where $\boldsymbol{s}$ represents the vector of the additional variables, i.e.

$$
\mathbf{s}=\left[\begin{array}{llll}
s_{1} & s_{2} & \cdots & s_{J}
\end{array}\right]
$$

The non-negativity condition ( $\mathbf{s} \geq 0$ ) is obtained by adding a negative sum of logarithmic functions, where each individual function depends on the additional variables (elements of the vector s), in the objective function, thus forming a logarithmic barrier, i.e.:

$$
\min f_{\gamma}(\boldsymbol{x})=f(\boldsymbol{x})-\gamma \sum_{j=1}^{J} \ln \left(s_{j}\right) .
$$

where $\gamma$ is a barrier parameter (internal penalty factor), which in the iterative solution procedure gradually approaches zero, as PDIP algorithm converges to the optimal solution. Accordingly to this, we obtain the augmented Lagrange function of the PDIP for solving nonlinear optimization problems, whose algorithm is formulated by expression (9), and is defined as follows:

$$
\begin{aligned}
L= & f(\mathbf{x})-\lambda^{T}\left(-h_{k}(\mathbf{x})\right)-\mu^{T}\left(-g_{j}(\mathbf{x})-\mathbf{s}\right)- \\
& -\gamma \sum_{j=1}^{J} \ln \left(\mathbf{s}_{j}\right) .
\end{aligned}
$$

where

$\lambda$ - vector of Lagrange multipliers for equality constraints,

$\boldsymbol{\mu}$ - vector of Lagrange (KKT) multipliers for inequality constraints.

Furthermore, these same Lagrange (or KKT) multipliers represent the dual variables of PDIP algorithm. The dual variables represent the change of objective function value, with respect to the change of the values of decision variables [17] and symbolically is expressed with the following vectors:

$$
\begin{aligned}
\lambda^{T} & =\left[\begin{array}{llll}
\lambda_{1} & \lambda_{2} & \cdots & \lambda_{K}
\end{array}\right] \\
\mu^{T} & =\left[\begin{array}{llll}
\mu_{1} & \mu_{2} & \cdots & \mu_{J}
\end{array}\right]
\end{aligned}
$$

In order for the solution to be optimal solution to the nonlinear optimization problem, the necessary first-order optimality conditions, i.e. KarushKuhn-Tucker conditions must be satisfied:

$$
\begin{gathered}
\nabla_{x} L=\nabla_{x} \mathbf{f}(\mathbf{x})+\lambda \nabla_{x} \mathbf{h}(\mathbf{x})+\boldsymbol{\mu} \nabla_{x} \mathbf{g}(\mathbf{x})=0 \\
\nabla_{\lambda} L=\mathbf{h}(\mathbf{x})=0 \\
\nabla_{\mu} L=\mathbf{g}(\mathbf{x})+\mathbf{s}=0 \\
\nabla_{S} L=-\gamma^{(k)} \mathrm{S}^{-1} \cdot \boldsymbol{e}+\boldsymbol{\mu}=0
\end{gathered}
$$

where:

$\nabla_{x} \mathbf{f}(\mathbf{x})$ - vector of first-order partial derivatives of the objective function,

$\nabla_{x} \mathbf{h}(\boldsymbol{x})$ - vector of first-order partial derivatives of the equality constraints,

$\nabla_{x} \mathbf{g}(\mathbf{x})$ - vector of first-order partial derivatives of the inequality constraints,

$\mathbf{S}$ - diagonal matrix of additional variables,

$\mathbf{e}-$ vector of ones.

This Lagrange function is solved iteratively by the Newton's method (taking into account the size of the iteration step calculated by Newton direction and Hessian matrix), until satisfactory predetermined accuracy is achieved $[3,6]$.

\subsection{One iteration of Newton's method for determining the increments of variables}

After defining the Lagrange function, we proceed to create matrix form of equation system for the corresponding optimization problem, where each matrix is made up of appropriate submatrices, with different dimensions $[18,19,20]$ :

where:

$$
\mathbf{A} \Delta \boldsymbol{x}^{s}=|\mathbf{b}|,
$$

A - matrix of the second partial derivatives given in (15), including the Hessian matrix of the Lagrangian function $\nabla_{x}^{2} L$,

$\Delta x^{S}$ - matrix with increments of all variables (primal, additional and dual),

b - free member of matrix equation equal to non-negative gradients. 
The solution of this system of equations yields the increments of all the variables involved in the iterative calculation process, and they serve to update the variables from the initial values until a final or optimal solution is obtained. In order for the system equations (17) to satisfy the Karush-KuhnTucker conditions, the system matrix must be positive semi-definite [17].

\subsection{Updating variables}

The primary, additional, and dual variables in the PDIP algorithm are updated as follows $[18,19]$ :

$$
\begin{aligned}
\mathbf{x}^{(k+1)} & =\mathbf{x}^{(k)}+k_{S} \alpha_{P} \Delta x \\
\mathbf{s}^{(k+1)} & =\mathbf{s}^{(k)}+k_{S} \alpha_{P} \Delta \mathbf{s} \\
\lambda^{(k+1)} & =\boldsymbol{\lambda}^{(k)}+k_{S} \alpha_{D} \Delta \boldsymbol{\lambda} \\
\boldsymbol{\mu}^{(k+1)} & =\boldsymbol{\mu}^{(k)}+k_{S} \alpha_{D} \Delta \boldsymbol{\mu}
\end{aligned}
$$

Scalar parameters $\alpha_{P}$ и $\alpha_{D}$ represent the step lengths of the primal and dual variables respectively. The scalar parameter $k_{s} \in 0,1$ represents a factor of certainty that imposes a strict condition for the non-negativity of the additional variables (elements of the vector $\mathbf{s}$ ) and the dual variables (elements of the vector $\boldsymbol{\mu}$ ) in each iteration. The parameter $k_{s}$ in most cases it is initially set to a value of 0.99995 , and its value is updated by multiplying iteratively by itself, which should contribute to achieving the non-negativity of the variables $\boldsymbol{S}$ and $\boldsymbol{\mu}$ (according to the non-negativity condition of the KKT conditions), so it applies in each iteration of the defined iteration process.

\subsection{Calculation of the step length of the primal and dual variables}

Determining the optimal step lengths of the primal, additional and dual variables is necessary for updating the variables in the vectors $\mathbf{x}, \mathbf{s}, \boldsymbol{\lambda}$ and $\boldsymbol{\mu}$. The step length parameter is updated in order to satisfy the non-negativity conditions of the variables $\mathbf{s}$ and $\boldsymbol{\mu}$. To achieve this, the maximum permissible step length for primal, additional and dual variables is calculated as follows [10, 19]:

$$
\begin{aligned}
\alpha_{p_{\mathrm{MAX}}} & =\min \left[\min _{\Delta s_{j}<0} \frac{s_{j}}{\left|\Delta s_{j}\right|}, 1\right] \\
\alpha_{D_{M A X}} & =\min \left[\min _{\Delta \mu_{j}<0} \frac{\mu_{j}}{\left|\Delta \mu_{j}\right|}, 1\right]
\end{aligned}
$$

where:

$$
j \text { - current index, with value of } 1, \ldots, J,
$$

$\alpha_{P \max }-$ maximum step length of primal and additional variables, ables,

$\alpha_{D \text { min }}-$ maximum step length of dual vari-

If $\alpha_{P \max }$ and $\alpha_{D \max }$ after calculation according to (22) and (23), they are an empty set, then they get an initial value of 0.001 . The maximum permissible step lengths are subjected to one more test, i.e.:

- If $\alpha_{P \max }$ is less than or equal to 0.001 , or greater than 0.9 , then it gets an initial value of 1 .

- If $\alpha_{D \max }$ is less than or equal to 0.001 , or greater than 0.9 , then it gets an initial value of 1 .

Finally, another modification is performed that contributes to maintaining the non-negativity of the $\mathbf{s}$ and $\boldsymbol{\mu}$ vectors. Expressions (24) and (25) calculate the step lengths $\alpha_{P}$ and $\alpha_{D}$, based on the already calculated maximum selected step lengths, which are divided by 1.13 , i.e.:

$$
\begin{aligned}
& \alpha_{P}=\frac{\alpha_{P \mathrm{MAX}}}{1.13}, \\
& \alpha_{D}=\frac{\alpha_{D \mathrm{MAX}}}{1.13} .
\end{aligned}
$$

In order to avoid the oscillatory convergence of the iterative process, it is acceptable to choose the lower value of $\alpha_{P}$ and $\alpha_{D}$, from expressions (24) and (25), and with that value to perform initialization of $\alpha_{P}$ and $\alpha_{D}$ for next iteration.

\subsection{Updating the barrier penalty factor}

To calculate the barrier penalty factor (barrier parameter), the complementary difference $\rho^{(k)}$ is the first calculated in each iteration, as a scalar product of vectors $\boldsymbol{\mu}^{(k)}$ and $\mathbf{s}^{(k)}$, i.e.:

$$
\rho^{(k)}=\left(\boldsymbol{\mu}^{(k)}\right)^{T} \cdot \mathbf{s}^{(k)} .
$$

Then, by using the complementary difference, the barrier penalty factor is calculated as:

$$
\gamma^{(k)}=\sigma \cdot \frac{\rho^{(k)}}{J},
$$

where $\rho, J, \sigma$ represent the complementary differen$\mathrm{ce}$, the number of the inequality constraints type, and the centering parameter (which usually has a value of 0.1 ), respectively.

\subsection{Convergence}

PDIP algorithm converges (iterative process is interrupted) when all four criteria are satisfied, i.e.: 


$$
\begin{aligned}
& v_{1}^{(k)} \leq \varepsilon_{1} \\
& v_{2}^{(k)} \leq \varepsilon_{1} \\
& v_{3}^{(k)} \leq \varepsilon_{1} \\
& v_{4}^{(k)} \leq \varepsilon_{\gamma}
\end{aligned}
$$

where

$$
\begin{gathered}
v_{1}^{(k)}=\max \left[\left\|\mathbf{h}\left(\mathbf{x}^{(k)}\right)\right\|_{\infty},\left\|\mathbf{g}\left(\mathbf{x}^{(k)}\right)\right\|_{\infty}\right] v_{2}^{(k)}= \\
=\frac{\left\|\nabla_{\mathbf{x}} f\left(\mathbf{x}^{(k)}\right)+\nabla_{\mathbf{x}} \lambda^{(k)} \mathbf{h}\left(\mathbf{x}^{(k)}\right)+\nabla_{x} \boldsymbol{\mu}^{(k)} \mathbf{g}\left(\mathbf{x}^{(k)}\right)\right\|_{\infty}}{1+\left\|\mathbf{x}^{(k)}\right\|_{2}} \\
v_{3}^{(k)}=\frac{\rho^{(k)}}{1+\left\|\mathbf{x}^{(k)}\right\|_{2}} \\
v_{4}^{(k)}=\gamma^{(k)}
\end{gathered}
$$

The parameter $v_{1}$ represents the maximum difference in the imbalance of the equality and inequality constraints in the defined system of equalities and inequalities. The parameter $v_{2}$ represents the infinite norm of the Lagrange function gradient, divided by the square root of the sum of squares of all variables. The parameter $v_{3}$ is the complementary difference, divided by the same divisor as is the case with $v_{2}$. The parameter $v_{4}$ is the barrier parameter. Typically used convergence criteria are $\varepsilon_{1}=$ $10^{-6}$ и $\varepsilon_{\gamma}=10^{-8}$.

\section{PROBLEM FORMULATION}

The study system is composed of $N T$ thermal power plants and $\mathrm{NH}$ hydropower plants, as well as NOIE wind power plants, which should meet the system load demand $P_{P}$ during the optimization period, which is divided into equal $J$ periods with duration of $T_{J}=1 \mathrm{~h}$. The main objective of STHTS is to optimally utilize the available water for maximum generation from hydropower plants, as well as production from each thermal unit, so that total fuel costs (objective function $F$ ) are minimized $[19,20]$ :

$$
\min F=\sum_{j=1}^{J} \sum_{t=1}^{N T} F_{t}(j) \cdot T_{j}
$$

It is assumed that $F_{t}$ is a quadratic function, i.e.

$$
F_{t}\left(P_{G T, t}\right)=a+b \cdot P_{G T, t}+c \cdot P_{G T, t}^{2} .
$$

\subsection{Constraints}

\section{a) Active power balance}

$$
\begin{gathered}
\sum_{t=1}^{N \mathrm{~T}} P_{G \mathrm{~T}, t}(\mathrm{j})+\sum_{h=1}^{N H} P_{G H, h}(\mathrm{j})+\sum_{v=1}^{N O I E} P_{G V, v}(\mathrm{j})= \\
=P_{P}(\mathrm{j})+P_{L}
\end{gathered}
$$

where the power losses in transmission lines $P_{L}$ are calculated using Kron's formula [1]:

$$
P_{L}=\sum_{i=1}^{N G} \sum_{j=1}^{N G} P_{G i} B_{i j} P_{G j}+\sum_{i=1}^{N G} B_{i 0} P_{G i}+B_{00}
$$

\section{b) Power generation limits}

Each thermal and hydrogenerating unit have their upper and lower power limit:

$$
\begin{gathered}
P_{G T, t}^{\min } \leq P_{G T, t} \leq P_{G T, t}^{\max } \\
P_{G H, h}^{\min } \leq P_{G H, h} \leq P_{G H, h}^{\max }
\end{gathered}
$$

\section{c) Water availability constraint}

The total available water discharge of each hydropower plant for the whole scheduled time horizon is limited by:

$$
\sum_{j=1}^{J} Q_{t h}(j) \cdot T_{j} \leq V_{h},
$$

where $Q_{t h}(j)$ is stream flow of hydropower plant $h$, in interval $j$, and is determined by:

$$
Q_{t h}\left(P_{G H, h}\right)=\alpha+\beta \cdot P_{G H, h}+\gamma \cdot P_{G H, h}^{2} .
$$

\section{d) Transmission line constraint}

The active power of the transmission line, i.e. between two buses, must be less than or equal to its maximum transmission capacity:

$$
\left|P_{G R, g}\right| \leq P_{G R, g}^{\max }, g=1, \ldots G,
$$

where $G$ represents the number of transmission lines (branches) in the system. Expression (39) takes the absolute value of transmission line power, since the power flows in some transmission lines may have opposite directions from the reference. Therefore, expression (39) can be represented as a constraint with two interrelated expressions:

$$
\begin{aligned}
P_{G R, g} & \leq P_{G R, g}^{\max } \\
-P_{G R, g} & \leq P_{G R, g}^{\max }
\end{aligned}
$$

Using the transmission line power dependence of the generator power $\mathbf{P}_{G R}=\mathbf{H} \cdot \mathbf{P}_{G}$ (where $\mathbf{H}$ is a 
matrix with $G$ rows and $N T+N H$ columns, obtained from the DC model, i.e. DC power flow, in which line resistances are negligible, i.e. $\mathrm{R} \ll \mathrm{X}, \sin (\theta)=$ 0 i.e. $\cos (\theta)=1$, and magnitudes of bus voltages are set to 1.0 p.u.), expressions (40) can be written in matrix form:

$$
\left[\begin{array}{r}
H \\
-H
\end{array}\right] \cdot P_{G}=\left[\begin{array}{c}
P_{G R}^{\max } \\
-P_{G R}^{\max }
\end{array}\right]
$$

\subsection{Decision vector}

From the problem formulation, $\mathbf{x}$ represents a decision vector (vector of decision variables), which is composed of the power out of hydro unit and the power out of thermal unit. Accordingly, it is composed of $(N T+N H) \cdot J=(4+5) \cdot 24=216$ variables, i.e.:

$$
\begin{gathered}
x=\left[P_{G T, 1}(j), P_{G T, 2}(j), P_{G T, 3}(j), P_{G T, 4}(j),\right. \\
\left.P_{G H, 1}(j), P_{G H, 2}(j), P_{G H, 3}(j), P_{G H, 4}(j), P_{G H, 5}(j)\right]^{T}
\end{gathered}
$$

\subsection{Formation of the Lagrange function}

According to the above, a barrier penalty factor is added to the Lagrange function $\gamma$, so the Lagrange function which is minimized by PDIP algorithm, is given by:

$$
\begin{aligned}
& L=\sum_{j=1}^{J} \sum_{t=1}^{N T} F_{t}(j) \cdot T_{j}+\sum_{j=1}^{J} \lambda_{j}\left(\sum_{t=1}^{N T} P_{G T, t}(j)+\right. \\
& \left.+\sum_{h=1}^{N H} P_{G H, h}(j)+\sum_{v=1}^{N O I E} P_{G V, v}(j)-P_{P}(j)-P_{L}\right)+ \\
& +\sum_{h=1}^{N H} \mu_{h}\left(\sum_{j=1}^{J} Q_{t h}(j) \cdot T_{j}-V_{h}+s_{v o d a, h}\right)+ \\
& +\sum_{t=1}^{N T} v_{t}^{\min }\left(\sum_{j=1}^{J} P_{G T, t}^{\min }(j)-P_{G T, t}(j)+s_{t}^{\min }\right)+ \\
& +\sum_{t=1}^{N T} v_{t}^{\max }\left(\sum_{j=1}^{J} P_{G T, t}(j)-P_{G T, t}^{\max }(j)+s_{t}^{\max }\right)+ \\
& +\sum_{h=1}^{N H} \psi_{h}^{\min }\left(\sum_{j=1}^{J} P_{G H, h}^{\min }(j)-P_{G H, h}(j)+s_{h}^{\min }\right)+ \\
& +\sum_{h=1}^{N H} \psi_{h}^{\max }\left(\sum_{j=1}^{J} P_{G H, h}(j)-P_{G H, h}^{\max }(j)+s_{h}^{\max }\right)+ \\
& +\sum_{g=1}^{G} \phi\left(\left|P_{G R, g}\right|-P_{G R, g}^{\max }+s_{g}\right)-\gamma \sum_{h=1}^{N H} \ln \left(s_{v o d a, h}\right)- \\
& -\gamma \sum_{t=1}^{N T} \ln \left(s_{t}^{\min }\right)-\gamma \sum_{t=1}^{N T} \ln \left(s_{t}^{\max }\right)-\gamma \sum_{h=1}^{N H} \ln \left(s_{h}^{\min }\right)- \\
& -\gamma \sum_{h=1}^{N H} \ln \left(s_{h}^{\max }\right)-\gamma \sum_{g=1}^{G} \ln \left(s_{g}\right)
\end{aligned}
$$

i.e.

$$
\begin{aligned}
L= & \sum_{j=1}^{J} \sum_{t=1}^{N T} F_{t}(j) \cdot T_{j}-\lambda^{T} h(x)- \\
& -\mu_{H}^{T}\left(-g_{v o d a}(x)-s_{v o d a}\right)- \\
& -v_{\min }^{T}\left(-g_{T, \min }(x)-s_{T, \min }\right)- \\
& -v_{\max }^{T}\left(-g_{T, \max }(x)-s_{T, \max }\right)- \\
& -\psi_{\min }^{T}\left(-g_{H, \min }(x)-s_{H, \min }\right)- \\
& -\psi_{\max }^{T}\left(-g_{H, \max }(x)-s_{H, \max }\right)- \\
& -\varphi^{T}\left(-g_{G R}(x)-s_{G R}\right)-\gamma \sum_{h=1}^{N H} \ln \left(s_{v o d a}\right)- \\
& -\gamma \sum_{t=1}^{N T} \ln \left(s_{T, \min }\right)-\gamma \sum_{t=1}^{N T} \ln \left(s_{T, \max }\right)- \\
& -\gamma \sum_{h=1}^{N H} \ln \left(s_{H, \min }\right)-\gamma \sum_{h=1}^{N H} \ln \left(s_{H, \max }\right)- \\
& -\gamma \sum_{g=1}^{G} \ln \left(s_{G R}\right)
\end{aligned}
$$

where:

$\lambda^{T}$ - matrix with Lagrange multipliers for equality constraints,

$h$ - matrix with equality constraints,

$\mu_{H}^{T}, v_{\min }^{T}, v_{\max }^{T}, \psi_{\min }^{T}, \psi_{\max }^{T}, \varphi^{T}-$ matrix with KKT (Karush-Kuhn-Tucker) multipliers for inequality constraints,

$g_{\text {voda }}, g_{T, \min }, g_{T, \text { max }}, g_{H, \text { min }}, g_{H, \text { max }}, g_{G R}$ matrices with inequality constraints,

$S_{\text {voda }}, S_{T, \min }, s_{T, \max }, S_{H, \min }, S_{H, \max }, S_{G R}$ matrices of integrated non-negative variables.

\section{APPLICATION OF THE PROPOSED METHOD TO SOLVE SHORT-TERM HYDROTHERMAL COORDINATION}

The study case is a modified IEEE 30 Bus Test System [23, 24, 25, 26] consisting of five hydropower plants, four thermal power plants, one wind power plant, 30 buses, and 48 transmission lines with maximum transmission capacity of each line, respectively. The aim is to perform STHTS with an optimization period of 24 hours. The optimization period is divided into 24 time intervals, with duration of 1 hour. The data for the load demand over study period (Figure 1) and the predicted power generated by the wind power plant (Figure 2), realtime data or hourly forecasts are taken for 30. 12 . 
2019, from the reference [21]. The power system which is subject to analysis is shown in Figure 3.

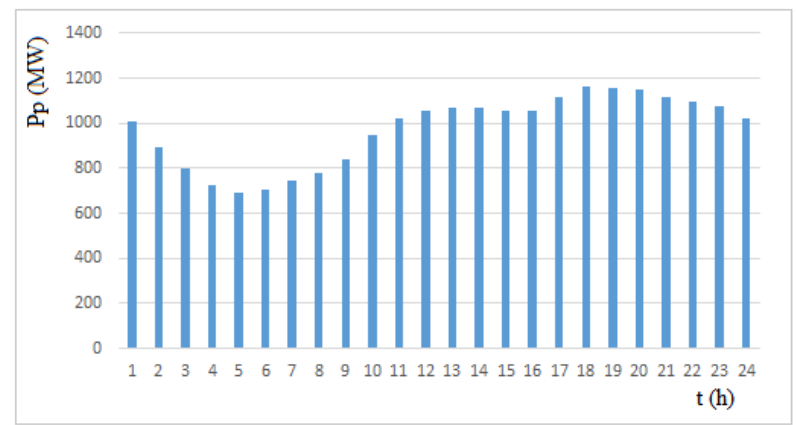

Fig. 1. Load demand over study period

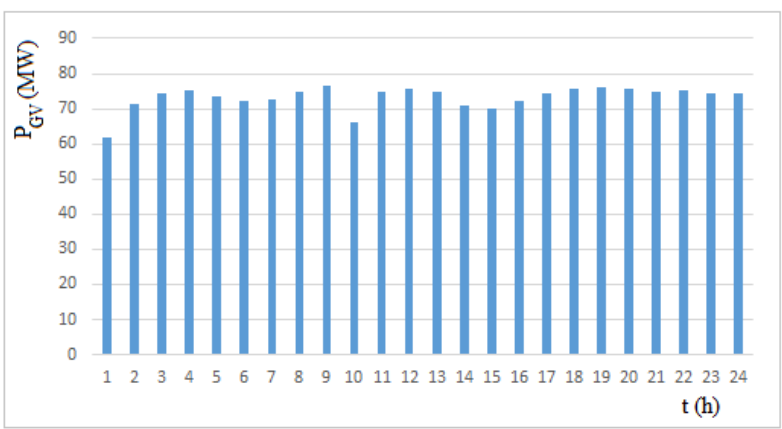

Fig. 2. Predicted power generated by the wind power plant

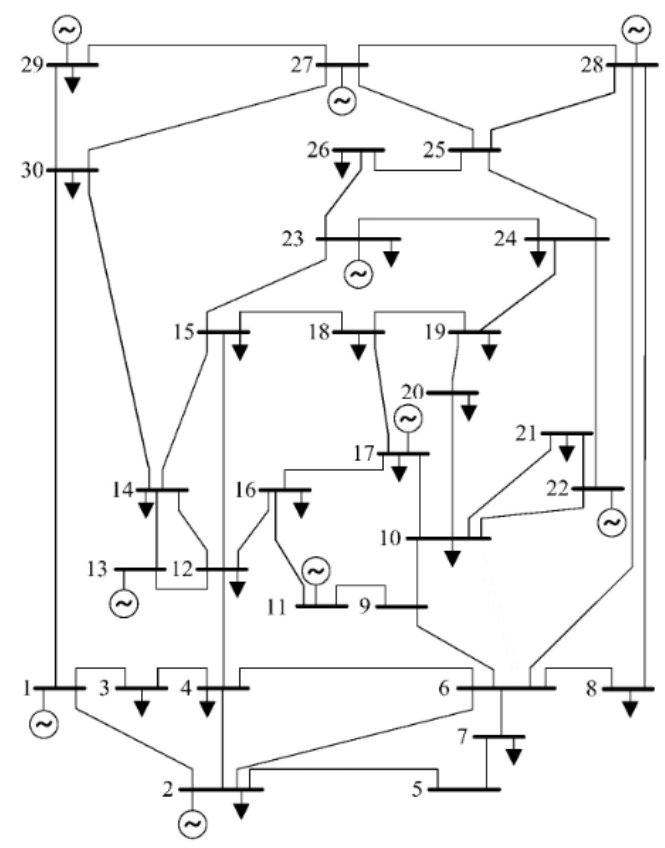

Fig. 3.. Modified IEEE 30 Bus systems

The thermal power plants TP 1, TP 2, TP 3 and TP 4 are located at the buses 1, 2, 22 and 23, respectively. The data for the thermal generating units: the fuel cost function coefficients, as well as their rated lower and upper power limit are shown in Table $1[22,27]$.

Table 1

Data for thermal generating units

\begin{tabular}{cccccc}
\hline \hline Unit & $a_{t}$ & $b_{t}$ & $c_{t}$ & $P_{G T . t}^{\min }$ & $P_{G T . t}^{\max }$ \\
& $(€ / \mathrm{h})$ & $(€ / \mathrm{MWh})$ & $\left(€ / \mathrm{MW}^{2} \mathrm{~h}\right)$ & $(\mathrm{MW})$ & $(\mathrm{MW})$ \\
\hline TP 1 & 35 & 2.041 & 0.00129 & 110 & 400 \\
TP 2 & 25 & 3.2 & 0.0025 & 50 & 400 \\
TP 3 & 30 & 3.4 & 0.0008 & 50 & 400 \\
TP 4 & 65 & 1.9 & 0.0026 & 120 & 300 \\
\hline \hline
\end{tabular}

The hydropower plants are located at the buses $11,13,17,28$ and 29, respectively, and the wind power plant at the bus 27 . The data for hydropower plants: the input-output characteristic coefficients, their rated lower and upper power limit, as well as the available amount of water in the reservoir, are shown in Table $2[22,28]$.

Table 2

Data for hydropower plants

\begin{tabular}{|c|c|c|c|c|c|c|}
\hline Unit & $\alpha_{h}$ & $\beta_{h}$ & $\gamma_{h}$ & $P_{G T, t}^{\min }$ & $P_{G T, t}^{\min }$ & $V_{\max }$ \\
\hline & $\left(\mathrm{m}^{3} / \mathrm{h}\right)$ & $\left(\mathrm{m}^{3} / \mathrm{MWh}\right)$ & $\left(\mathrm{m}^{3} / \mathrm{MW}^{2} \mathrm{~h}\right)$ & $(\mathrm{MW})$ & (MW) & $\left(10^{5} \mathrm{~m}^{3}\right)$ \\
\hline HP1 & 56.067 & 8.665 & 0.0061 & 0 & 120 & 7.0792 \\
\hline HP2 & 26.505 & 17.330 & 0.0100 & 0 & 120 & 5.9465 \\
\hline HP3 & 1.98 & 0.306 & 0.000216 & 30 & 110 & 10 \\
\hline HP4 & 0.936 & 0.612 & 0.0002 & 40 & 110 & 10 \\
\hline HP5 & 1.58 & 0.512 & 0.0003 & 30 & 110 & 8 \\
\hline
\end{tabular}

Optimization will also consider transmission losses, whose B coefficients matrices are given in [27].

In order to emphasize the impact of the transmission network on the operating costs of thermal power plants, the security constraint for the maximum transmission capacity of each transmission line in the system will be considered. The data for the transmission lines of the system are given in [27].

Accordingly, two cases will be analyzed: 
- Case 1: STHTS with considered transmission losses and neglected transmission line constraint.

- Case 2: STHTS with considered transmission losses and considered transmission line constraint.

\subsection{Results and analyses}

From the results it follows that the total operating cost in the power plants in the first case are $30,567.7$, while the second case are $36486,4 €$. The total generation from thermal power plants is
12547.96 MWh, which represents $51 \%$ of the total electricity generation. Hydropower plants generate a total of $10373.44 \mathrm{MWh}$, which represents $42 \%$ of total electricity generation. The remaining part of $7 \%$, i.e. $1757,73 \mathrm{MWh}$ covers wind power plant. Total transmission losses in the system during the whole optimization period are $1322.03 \mathrm{MWh}$, i.e. average $5.19 \%$ of total generation in all intervals $(24 \mathrm{~h})$. The optimal power output of the thermal power plants and hydropower plants are presented in Figure 4 and Figure 5. The results for the transmission line active power (DC - OPF) during the whole optimization period are presented in Table 3.

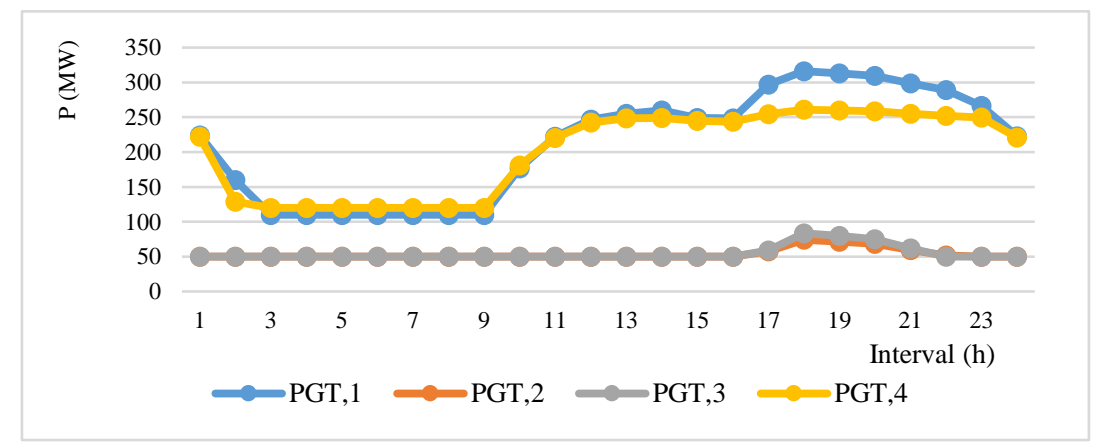

Fig. 4. Optimal hourly power generation of thermal plants

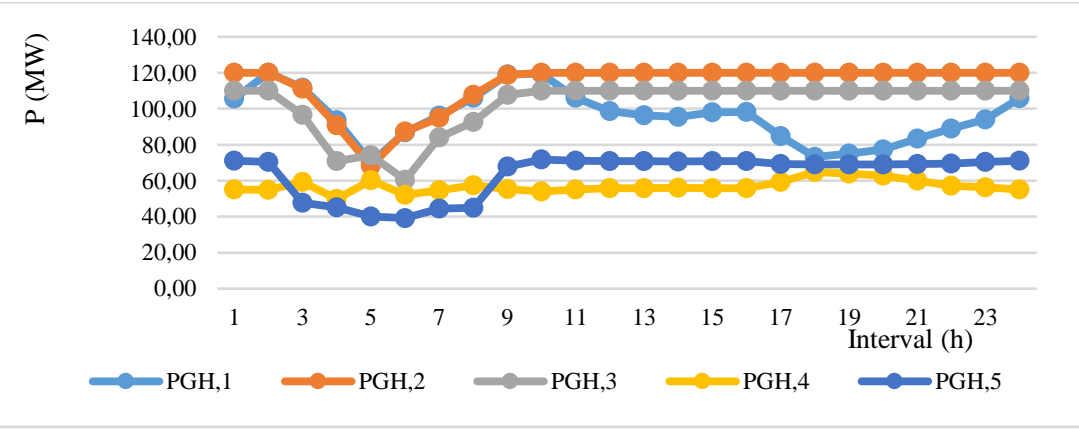

Fig. 5. Optimal hourly power generation of hydropower plants

\section{CONCLUSION}

Harmonization of power generation through STHTS is an important activity in complex hydrothermal power systems, which on the basis of technical and economic optimization criteria, provides the opportunity for optimum utilization of thermal and hydro generating units.

The mathematical models of power plants, reservoirs, as well as the mathematical model of the optimization problem presented by Lagrange function, could be used to develop the optimal planning methodology. For the one-day optimization period, hydropower mathematical models are performed by neglecting the water flow balance equation in reservoir.
As theoretically explained, the Primal-Dual Interior Point (PDIP) algorithm, which as a global optimization method for nonlinear programming, is applied to nonlinear optimization problems with high dimensionality (large scale optimization problems), because it has great versatility and the ability to solve sparse matrices. The main contribution of this study is solving the optimization problem by considering the transmission line constraint and integrating forecasted wind power plant production.

This paper, with its content, can serve for future to extend models of STHTS optimization problem, for various constraints, load diagrams, number of generators, hydrological conditions and the like. 


\section{Table 3}

\section{Optimal power flow of transmission lines (MW)}

\begin{tabular}{|c|c|c|c|c|c|c|c|c|c|c|c|c|c|c|c|c|c|c|c|c|c|c|c|c|}
\hline ne & & & $5 \mathrm{n}$ & $\mathrm{h}$ & & & h & & $9 \mathrm{n}$ & h & & $12 \mathrm{~h}$ & $\mathrm{~h}$ & $\mathrm{~h}$ & $\mathrm{~h}$ & $\mathrm{~h}$ & $\mathrm{~h}$ & $\mathrm{~h}$ & $\mathrm{~h}$ & $\mathrm{~h}$ & $\mathrm{~h}$ & $\mathrm{~h}$ & $3 \mathrm{~h}$ & th \\
\hline 1 & .0 & & & & & & 1 & & .5 & 144.4 & 3 & .5 & 0.3 & 2.4 & 7.7 & 7.2 & 5.9 & 6.5 & 6.4 & 6.3 & .9 & 5.5 & 35.6 & 5.5 \\
\hline & & & & & & & & & & 4 & & & & & & 3 & & & & & & 4 & 3 & 6.8 \\
\hline & & & & & & & & & .7 & .7 & & .2 & 9 & -9.6 & 0.1 & 0.1 & & & 6 & & 4.5 & 1 & .1 & \\
\hline & & & & & & & & & & & & & & & & & & & & & & & & \\
\hline & 5.9 & & 1 & 97.3 & & & 101.1 & & & & & & & & & & & & & & & & & 155. \\
\hline & 64 & 29 & 6.9 & -3.8 & -3.8 & & -5.0 & -6.3 & -7.3 & -7.3 & -6.4 & -6.0 & -5.7 & -5.3 & -6.0 & -6.0 & & 61 & 5.2 & 4.1 & 1.1 & 17 & -4.5 & -6.4 \\
\hline & 16.5 & 25.3 & 13.5 & 10.9 & 4.4 & & 10 & 12.9 & 16.8 & 16 & 16 & 16 & 16.3 & 17 & 16 & 16 & 23 & 26 & 7 & 25.2 & 23.8 & 22.4 & 18.3 & 16. \\
\hline & 9.1 & .0 & \begin{tabular}{|l|} 
\\
\end{tabular} & -78.8 & 3.2 & 4.9 & -8 & 7 & 3.2 & -118.4 & -128.8 & -134.5 & -1 & -136.6 & -135.1 & -134.8 & -137.2 & -131.4 & 3 & -13 & .5 & 2 & . & -128 \\
\hline & 0.2 & 5.6 & 152.6 & 3.5 & 5.0 & 7.7 & 139.6 & 148.2 & 162.5 & 193.5 & 209.6 & 218.5 & 221.3 & 222.0 & 219.4 & 219.0 & 226.6 & 225.6 & 225.8 & 226.0 & 226.5 & 6.8 & 223.0 & 209. \\
\hline & 2.0 & & & & & & & & & & -111.0 & & & -130.0 & 7.3 & & -1 & .0 & .0 & \begin{tabular}{|l|}
-130.0 \\
\end{tabular} & .0 & & & \\
\hline & 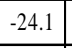 & & 4 & 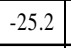 & & & -29.2 & & & & -24 & 6 & & -16.1 & & & & & & & & & & \\
\hline & 15 & & & & & & & & & & & & & & & & & & & & & & & 246 \\
\hline & 684 & & 2.1 & 16 & 77 & & -53.0 & & 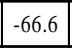 & -6 & -5 & 5 & $\mid-53.3$ & -5 & 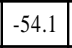 & 3 & 1 & & & & & & & -58 \\
\hline & 343 & 253 & 23.7 & 26.5 & 21.9 & & 23.8 & 23.5 & 224 & 30.8 & 34.2 & 36.0 & 36.6 & 36.7 & 36.2 & 36.1 & 384 & 41 & 0.8 & 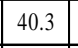 & & & & 342 \\
\hline & 8.7 & 4.8 & 1.2 & 2.0 & 3.8 & .1 & \begin{tabular}{|l|}
-24.4 \\
\end{tabular} & 9.3 & 5.6 & \begin{tabular}{|l}
-30.9 \\
\end{tabular} & -25 & 3.1 & -22.3 & -22 & -22.8 & -23.0 & \begin{tabular}{|l|}
-18.7 \\
\end{tabular} & 0 & 4.8 & \begin{tabular}{|l|} 
\\
\end{tabular} & -18.2 & 20.5 & 21.7 & 25 \\
\hline & 5.5 & 3 & .2 & 0.6 & .9 & 3.1 & -73.4 & 2.7 & .2 & -93.8 & \begin{tabular}{|l|}
-95.4 \\
\end{tabular} & 5.3 & .5 & -96.7 & 5.3 & 5.3 & \begin{tabular}{|l|}
-98.1 \\
\end{tabular} & 3 & .1 & -98 & 3.2 & 7.6 & 96. & 35. \\
\hline & 1.4 & 7.2 & .2 & & 1. & 4.7 & 0.9 & 9.4 & & 5. & 1.6 & -0.7 & & -1 & -0 & 0.8 & -3 & -8 & -8.4 & 1 & & -4.3 & -2.4 & 1.5 \\
\hline & 1.3 & & & & & & 25.1 & & & 30.1 & 3 & 1.0 & 32.0 & 32. & & & 32.9 & & & & & & & 31.2 \\
\hline & 27 & & & & & & & & & -9.8 & -3. & & & & & & & & & & & & & 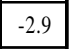 \\
\hline & & & & & & & & & & & & & & & & & & & & & & & & \\
\hline & 320 & 04 & & & & & 249 & & & 32.0 & 32. & 320 & 32.0 & 320 & 320 & 320 & 320 & & & & & & & 328 \\
\hline 2 & 2.8 & -3.7 & & 0 & 0 & & -2.6 & -41 & & -1.7 & 2.7 & 5. & & 62 & & 5.2 & & & & 12 & & & 67 & 2.7 \\
\hline 23 & 5.9 & 0.3 & 7.2 & 5.5 & 3.9 & 2.0 & -22.3 & -25.6 & 1.3 & -2 & -26 & -24.7 & -24.2 & -24 & 24.5 & -24.6 & -2 & -20.1 & 20.4 & -20 & & 22 & & -26. \\
\hline 24 & .7 & .3 & .6 & 9.3 & 1.5 & .0 & \begin{tabular}{|l|}
-45.9 \\
\end{tabular} & 0.4 & 8.1 & \begin{tabular}{|l|}
-59.8 \\
\end{tabular} & -59. & -59.7 & \begin{tabular}{|l|}
-59.7 \\
\end{tabular} & -59. & $\mid-5$ & \begin{tabular}{|c|} 
\\
\end{tabular} & \begin{tabular}{|l|}
-59.4 \\
\end{tabular} & $\mid-5$ & -59.4 & -59.4 & -59.4 & 59.4 & -59 & -59. \\
\hline 25 & 2.4 & 1.0 & 3.3 & 6.2 & 87 & .3 & -32.6 & 6.5 & -43.4 & -42.9 & -42.5 & -42.2 & -42.1 & \begin{tabular}{|l|}
-42.1 \\
\end{tabular} & -42.2 & -42.2 & -42.0 & -41.6 & +1.6 & -41.7 & -41.9 & 2.1 & -42. & -42. \\
\hline & & & & & & & & & & & -6 & & & -0 & & & & & & & & & & 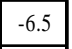 \\
\hline & & & & & & & & & & & & & & & & & & & & & & & & \\
\hline & & & & & & & & & & & & & & & & & & & & & & & & \\
\hline 29 & 179 & & & 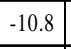 & & & . & -10.1 & & -14.5 & -17.8 & & & -20.4 & & & & & & & & & & 179 \\
\hline 3 & 77. & & & 1 & & & 12.3 & & 14.9 & 16.8 & 17. & 18.2 & 18.3 & 18 & 18.2 & 18.2 & 19.6 & & 2 & 20.1 & 19.7 & 19.3 & 18.7 & 17.7 \\
\hline 31 & 0. & 5.5 & 5.8 & 2. & 0. & 0 & 3.6 & 5. & 6.7 & 3.8 & 0. & -1.4 & -1.9 & -2 . & -1. & -1.5 & -4. & -7.4 & 6.9 & -6.4 & -4.9 & 3.5 & 2.4 & 14 \\
\hline 3 & 4. & & & 2. & & & & & & & 4. & & & & & & & & & & & & & .5 \\
\hline 5 & & & & & & & & & & -1 & -14 & & -18 & -18 & & & -21 & & & -24 & & & -19 & 14 \\
\hline & & & & & & & & & & & & & & & & & & & & & & & & \\
\hline & & & & & & & & & & & & & & & & & & & & & & & & \\
\hline & & & & & & & & & & & & & & & & & & & & & & & & -10.2 \\
\hline 37 & -32.0 & 60 & -20.4 & .5 & & -16.7 & \begin{tabular}{|l|}
-19.0 \\
\end{tabular} & 2 & 298 & \begin{tabular}{|l|}
-32.0 \\
\end{tabular} & \begin{tabular}{|l|} 
\\
\end{tabular} & -32.0 & .0 & -32 & -32.0 & .0 & -3 & -32.0 & -32.0 & 0 & -32.0 & -32.0 & & -32.0 \\
\hline 38 & 0. & 0. & 1. & 1. & & & & & 2.5 & 1.5 & 0.6 & 0.2 & 00 & -0.1 & & 02 & -1.5 & & -2.0 & -19 & -1 & -1.3 & & 0.6 \\
\hline 39 & & & & & & & & & & 31.9 & 30 & & 29. & 29 & 30. & 30.1 & 27. & 27 & 27. & 27 & & 28. & 29 & 30.7 \\
\hline 40 & 5 & & & -4 & & & & -1.3 & & & 3.0 & & & & & & & & & & & ${ }^{\circ}$ & & 3.0 \\
\hline 41 & -64.0 & 0.0 & -39.0 & .0 & & -47.6 & -53.4 & -57.0 & -63.5 & -64.0 & -64.0 & -04.0 & -64.0 & -64.0 & -04.0 & -64.0 & -04.0 & -04.0 & 0 & -64.0 & \begin{tabular}{|l} 
\\
\end{tabular} & -64.0 & -64.0 & -04.0 \\
\hline 42 & & & & & & & -1.3 & & & & 20.3 & & & & 51.2 & & & 66.4 & & & 53.4 & 46.3 & & 20.5 \\
\hline . & + & & & & & & & & & & +4 & -21.4 & & 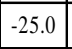 & & & 0.0 & + & & -43.6 & & & & $1+., 2$ \\
\hline 44 & & 46 & & 1.9 & & & & & & & & & & & & & & & & & & & & 18 \\
\hline 45 & -4.6 & & & -2.5 & & & & & & & & & & -8. & & -7.8 & & & 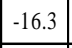 & -15 & 2.6 & -10.2 & -9.1 & -4.4 \\
\hline 46 & & & & & & & 43 & & & & 47. & 44. & & 42. & 4. & .0 & 37 & 32 & 4 & 34 & 7.1 & 9.5 & 2.0 & 47.4 \\
\hline 47 & -6.5 & -4.5 & -2.5 & -1 & -3 & -0.8 & -2.6 & -2.6 & -3.4 & -4.4 & -6. & -7.5 & -7.8 & -8.0 & -7.6 & 5 & -9. & -11 & -11.1 & -10.8 & 9 & 9.1 & 8.2 & -6.4 \\
\hline+0 & & . & 11.1 & 7. & 6.8 & 6 & 9 & 5 & 2.4 & .9 & 1.0 & .5 & 0.3 & 10.3 & 10.4 & 4 & 9. & 8.9 & 9.1 & 9.2 & 9.6 & 10.0 & 10.2 & 11.0 \\
\hline
\end{tabular}




\section{REFERENCES}

[1] Calović, M., Sarić, A., Stefanov, P.: Eksploatacija elektroenergetskih sistema u uslovima slobodnog trźista, Tehnički fakultet - Čačak, Beograd, 2005.

[2] Kothari, D. P., Nagrath, I. J.: Modern Power System Analysis, Third edition, McGraw-Hil, 2003.

[3] Erkmen, I., Karatas, B.: Short-term hydrothermal coordination by using multi-pass dynamic programming with successive approximation, in: 7th Mediterranean Electrotechnical Conference, Vol. 3, pp. 925-928 (1994).

[4] Oliveira, G. G., Soares, S.: A second order network flow algorithm for hydrothermal scheduling, IEEE Trans. Power Syst, Vol. 10, No 3, pp. 1635-1641 (1995).

[5] Habibollahzadeh, H., Bubenko, J. A.: Application of decomposition techniques to short term operation planning of hydrothermal power system, IEEE Trans. Power Syst, Vol. 1, No 1, pp. 41-47 (November 1998).

[6] Chang, G. W., Aganagic, M., Waight, J. G., Medina, J., Burton, T., Reeves, S., Christoforidis, M.: Experiences with mixed integer linear programming based approaches on short-term hydro scheduling, IEEE Trans. Power Syst, Vol. 16, No 4, pp. 743-749 (2001).

[7] Salam, M. S., Nor, K. M., Hamdam, A. R.: Hydrothermal scheduling based Lagrangian relaxation approach to hydrothermal coordination, IEEE Trans. Power Syst. 13 (1) 226-235 (1998)

[8] Torres, G. L., Quintana, V. H.: An Interior-Point Method for Nonlinear Optimal Power Flow Using Voltage Rectangular Coordinate, IEEE Trans. On Power Systems, Vol. 13, No. 4, pp. 1211-1218 (1998).

[9] Soliman, A., Mantawy, A. H.: Modern Optimization Techniques with Applications in Electric Power Systems, Springer, 2012.

[10] Luenberger, D. G., Ye, Y.: Linear and Nonlinear Programming, Fourth Edition, Springer, 2016.

[11] Castillo, E., Gonejo, A. J., Pedregal, P., Garciá, R., Alguacil, N.: Building and Solving Mathematical Programming Models in Engineering and Science, John Wiley \& Sons, 2001.

[12] Karmarkar, N.: A new polynomial-time algorithm for linear programming, Combinatorica, Vol. 4, No. 4, pp. 373-395 (November 1984).

[13] Frisch, K. R.: The Logarithmic Potential Method of Convex Programming, University Institute of Economics, Oslo, Norway, Manuscript, 1955.
[14] Dikin, I. I.: Iterative solutions of problems of linear and quadratic programming, Soviet Mathematics Doklady, Vol. 8, pp. 674-675 (1967)

[15] Fiacco, A. V., McCormick, G. P.: Nonlinear Programming: Sequential Unconstrained Minimization Techniques, John Wiley \& Sons, 1968.

[16] Khachiyan, L. G.: A polynomial algorithm in linear programming, Dokl. Akad. Nauk SSSR, Vol. 244, 1979, pp. 1093-1096.

[17] Lasdon, L. S.: Optimization Theory for Large Systems, Dover Publication Inc, New York, 2002.

[18] Rao, S. S.: Engineering Optimisation - Theory and Practice, Fourth edition, John Wiley \& Sons, Hoboken, New Jersey, 2009.

[19] Zhu, J.: Optimization of power system operation, Second edition, John Wiley \& Sons, IEEE Press, USA, 2015.

[20] Kimball, L. M., Clements, K. A., Davis, P. W., Nejdawi, I.: Multiperiod hydrothermal economic dispatch by an Interior Point method, Mathematical Programming Models in Engineering, Vol. 8, pp. 33-42 (2002).

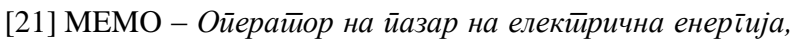
Конечни часовни йрогнози за ППЕЕ, http://opee.mepso.com.mk/Public/Post.aspx? $\mathrm{Id}=4 \mathrm{a} 34 \mathrm{ce} 88$ $-9121-42 d 5-8 \mathrm{a} 58-6718 \mathrm{cbd} 37 \mathrm{c} 87$.

[22] Николова Поцева, С.: Влијание на обновливите извори на елекиирична енеріија врз рабойайа на йроизводни-

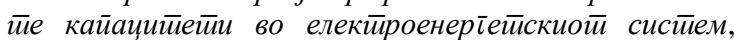
Докторски труд, Скопје, 2012.

[23] Nguyen, T. T., Ngoc, D., Truong, A. V., Ho, L. D.: Metaheuristic algorithms for solving hydrothermal system scheduling problem considering constraints in transmission lines, Global Journal of Technology \& Optimization, Vol. 7, 192 (2016).

[24] Guvenc, U., Altun, B. E., Duman, S.: Optimal power flow using genetic algorithm based on similarity, Energy Education Science and Technology, Part A: Energy Science and Research, Vol. 29, pp. 1-10 (2012).

[25] http://www.fglongatt.org/Test_Systems/IEEE_30bus.html.

[26] https://icseg.iti.illinois.edu/power-cases/.

[27] Pattanaik, J. K., Basu, M., Dash, D. P.: Opposition-based differential evolution for hydrothermal power system, Protection and Control of Modern Power Systems, 2017. DOI 10.1186/s41601-017-0033-5.p 